\title{
Using Board Game Through Ttw Strategy in Descriptive Writing
}

\author{
Nur Sholikha Muntiari, nurmuntiari@gmail.com, English Language Education Study \\ Program of Universitas Muhammadiyah Sidoarjo, Sidoarjo, Indonesia \\ Fika Megawati, fikamegawati@umsida.ac.id, English Language Education Study Program \\ of Universitas Muhammadiyah Sidoarjo, Sidoarjo, Indonesia
}

\begin{abstract}
This research aims to find out the effect of using board game through TTW strategy on seventh grade students' writing skill in descriptive text. Quasi-experimental design was implemented to the seventh grade in one of junior high school. The subject of this study was the whole population of seventh grade students in junor high school, in total 81 students. The data collection was taken from pre-test and post-test. The average score of experimental group is 73.81, and the average score of control group is 57.46. Moreover, the hypothesis test shows that $\mathrm{H}_{\mathrm{o}}$ is rejected because $\mathrm{t}_{\text {counting }}(5.71)$ is higher than table (2.31). In TTW strategy the students collaborate between three activities those are Think, Talk, and Write. TTW strategy is more effective becausethe students have enough time in learning process in a class. Additionally, the result of this study indicates that using board game through TTW strategy gives significant effect for developing English writing skill.

Keywords: Board Game, TTW Strategy, Descriptive Text
\end{abstract}

\section{INTRODUCTION}

Language is one of key terms to communicate with other people to show the expression, message, ideas, opinion, and fillings in written or spoken thought in verbal or non verbal language based on Nurfaujiyah and Riandi (2013). In English, there are four big skills should be mastered, that are in reading skill, writing skill, listening skill, and speaking skill. Some activities of the students in a class are speaking and writing to finish their work. Almost their assignments is using writing skill, it is a reason learning writing skills become very important. However, some of students have difficulty in English particularly in writing skill. Based on Ramadani and Saun (2013) that writing skill there are four items should be concerned. The first, students have to concern about diction of the word. Second, students should be able to organize the idea. Third, students have to regard in grammatical meaning. The last is paying attentions about the punctuations and rhetorical structure of the text.

Based on standard of competency and basic of competence in curriculum 2013, the student of junior high school has a basic competence to study about descriptive text in a seventh and eighth grade. In a syllabus of seventh grade, especially in 3.10 and 4.11 discussing about descriptive text. Describing animals is chosen for the theme in this research. Some of people have a pet, it is helping to describe based on their experience. Based on pre-observation, the students have a problem with the score of their writing skill. Based on teacher's statement, that students have difficulty in writing. Some of student's writing in seventh grade in one of junior high school was still low. Learning process need media to make classroom more active and have fun. Some of students have motivation and have a spirit when the teacher gives interesting learning media. In

46 | IJET $\mid$ Volume. 10, Issue 1. July 2021

Copyright 2021 Nur Sholikha Muntiari and Fika Megawati are licensed under Creative Commons AtrributionShareAlike 4.0 International License. 
addition, it makes the students easier to understand about the material (Setyadi and Qohar, 2017). Beside that, based on Arif's study (2018), play a game can make the students has a big motivation to be a winner from this game.

Using board game to be a media in learning descriptive text at seventh grade in junior high school. In board game the students can help to improve English skills, especially in writing skill. Based on Arif (2018) said that one of the important things in cooperative learning is about giving support in each other not only about working together. One group should be building good communication each member of group. In addition, one of the crucial aspects is how the entire assignment is processed rather than only completing it.

Think-Talk-Write or TTW strategy that is introduced by Huinker and Laughlin (1996). It is one of the strategies that is appropriate for writing skill in the learning process, particularly in descriptive text. In teaching descriptive text, those are three main activities. The first is thinking activity, the students think after what they have done a read about the material. Second, the students discuss and share with the other friends about what they read. The last activity is writing a text in a form available based on Suminar and Putri's study (2015). After they get a conclusion they should write a full text in an answer sheet available. Based on the problem statement above, the researcher have carried out experimental teaching by using board game trough TTW strategy to the seventh grade students especially writing skill in descriptive text junior high school. The research question is formulated as follow there is any significant effect of the using board game trough TTW strategy on the seventh grade students' writing skill in descriptive text at junior high school.

\section{METHOD}

This study used quantitative research which quasy-experimental design. The object or the participants by using nonrandom system which selected two of classes in seventh grade of junior high school that were as a experimental group and control group. In experimental group it was a Class VII B whom only male studentds while VII A whom female students only and VII C whom male and female students as control group. In experimental group used a board game and did by TTW strategy, while the control group learning as a usual method as like the main teacher. Whereas, both of them got a pre-test and post-test.

There were three steps to analysis the data that are normality test, homogeneity test and the last is hypothesis test. The normally distributed that the data is more $\alpha=0,05$ and used T-test to find out the means and standard deviations of two samples and to make a comparison. Homogeneity test is intended to find out whether there are different variants or not of two or more groups of data samples from populations that having same variants. To find out and analyze it the researchers used Microsoft Excel 2007. Rubric is one of important point to give the score of students' writing. One of the scoring rubrics can adopt from Brown (2007) as can be seen in the figure below:

47 | IJET $\mid$ Volume. 10, Issue 1. July 2021

Copyright 2021 Nur Sholikha Muntiari and Fika Megawati are licensed under Creative Commons AtrributionShareAlike 4.0 International License. 


\begin{tabular}{|c|c|c|c|}
\hline Anect & 'Bore & Waghimg & "Ferformace Derripiou \\
\hline \multirow{4}{*}{$\begin{array}{c}\text { Coutent } \\
\text { (C) } \\
30 \% \\
\text { - Topis } \\
\text {-Desals }\end{array}$} & 4 & \multirow{4}{*}{$3 x$} & $\begin{array}{l}\text { The tope is complets, elear and be deaile are relring to be } \\
\text { topis }\end{array}$ \\
\hline & 3 & & $\begin{array}{l}\text { The topie it complete and elear bot be detail are slmot relating } \\
\text { to the topis }\end{array}$ \\
\hline & 2 & & $\begin{array}{l}\text { The topie a complete and elear bot be detail are aot redating to } \\
\text { the topis }\end{array}$ \\
\hline & I & & 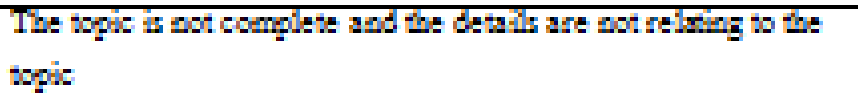 \\
\hline \multirow{2}{*}{$\begin{array}{c}\text { Orgamination } \\
(0) \\
20 \%\end{array}$} & 4 & \multirow{4}{*}{$2 \pi$} & 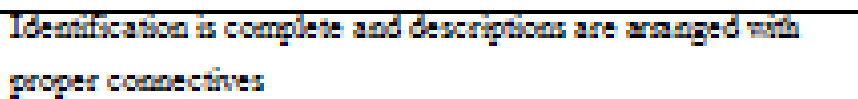 \\
\hline & 3 & & 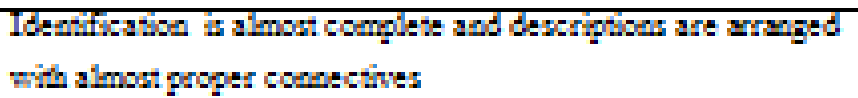 \\
\hline \multirow[b]{2}{*}{ Descrption } & 2 & & 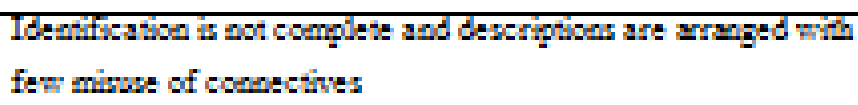 \\
\hline & $\mathbf{T}$ & & 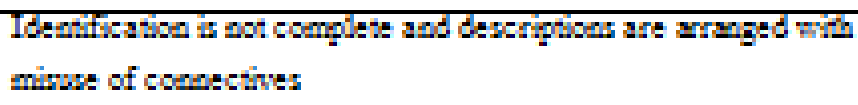 \\
\hline \multirow{3}{*}{$\begin{array}{c}\text { Grammar } \\
\text { (G) } \\
20 \% \\
\text { Ure Present } \\
\text { Tense }\end{array}$} & 4 & \multirow[b]{4}{*}{$2 \mathrm{x}$} & Wery few grammatieal or ayement eacroader \\
\hline & 3 & & $\begin{array}{l}\text { Fet grammatial or agreement inococades bot ovt affect on } \\
\text { meacing }\end{array}$ \\
\hline & 2 & & Wemerou grammatical or agrement tacersies \\
\hline Tense & I & & Frequent grammatisal or agrement tacovaries \\
\hline \multirow{4}{*}{$\begin{array}{c}\text { Vocabolary } \\
\text { (N) } \\
1 . \%\end{array}$} & 4 & \multirow{4}{*}{$1.5 \pi$} & 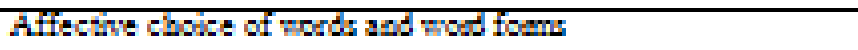 \\
\hline & 5 & & 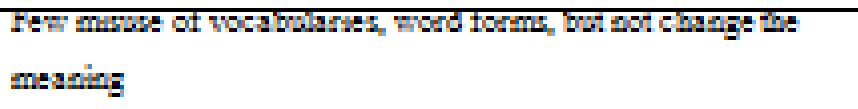 \\
\hline & 2 & & Lemined range coufwing worda and avod foms \\
\hline & I & & 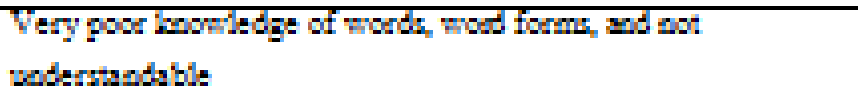 \\
\hline \multirow{4}{*}{$\begin{array}{c}\text { Mechamer } \\
\text { (M9) } \\
13 \% \\
\text { Spetling } \\
\text { Peotisation } \\
\text { Copitalization }\end{array}$} & 4 & \multirow[b]{4}{*}{$1,5 \pi$} & It wes correct pelling pootsation and copializatiod \\
\hline & 3 & & 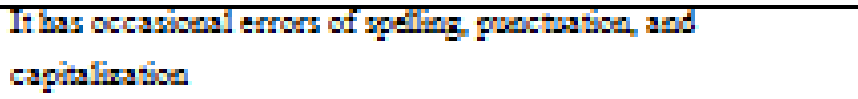 \\
\hline & 2 & & 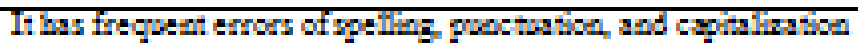 \\
\hline & $\mathbb{T}$ & & 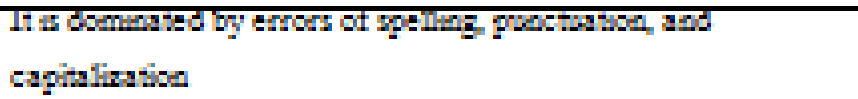 \\
\hline
\end{tabular}

Adapted from Brown (2007)

48 | IJET| Volume. 10, Issue 1. July 2021 Copyright 2021 Nur Sholikha Muntiari and Fika Megawati are licensed under Creative Commons AtrributionShareAlike 4.0 International License. 
Figure 1. Creteria for scoring in writing skill

$$
\text { Score }=\frac{3 C+2 O+2 G+1,5 V+1,5 M}{40} \times 10
$$

Moreover, playing a game can make the students has big motivation to be a winner from a game itself (Arif, 2018). Used board game to be a media in learning descriptive text at seventh grade in one of junior high school. In board game, the students help to improve English skills, especially in writing skill. According to Putri and Sukirlan (2017) state that a board game as a game which collaboration between counting or moving the pieces from one place to another places with give the pre-marked before on the board. In addition, board game is a game that consist of turn around and the members of the gamers' moved the own token in until the end of that path (Arif, 2018). Board game is a one of interactive game to apply in learning process though as a media or just giving the students warming up (Putri and Sukirlan, 2017). In addition, from Metom (2013) statements that a board game is a game which use a game board, cards consist of relation of the material, movers, a dice, and answer sheet.

The design of this board game is made by coreldraw 7.0 application. It modified from monopoly and snack and ladders game. In this game have to played in a group that consist of 5-6 members. Then, choose the player who is the first, second, third player, etc to play it. In each player have to stop based on dice number and then they would get a clue-card. In clue-card there is a random sentence which has to rearrange to make a good sentence with discussion in each group and write it in answer sheet (applied of think and talk activity in TTW strategy). The next player has to continue it until the clue-card has got all. Write down a short paragraph descriptive text in available answer (applied of write activity in TTW strategy).

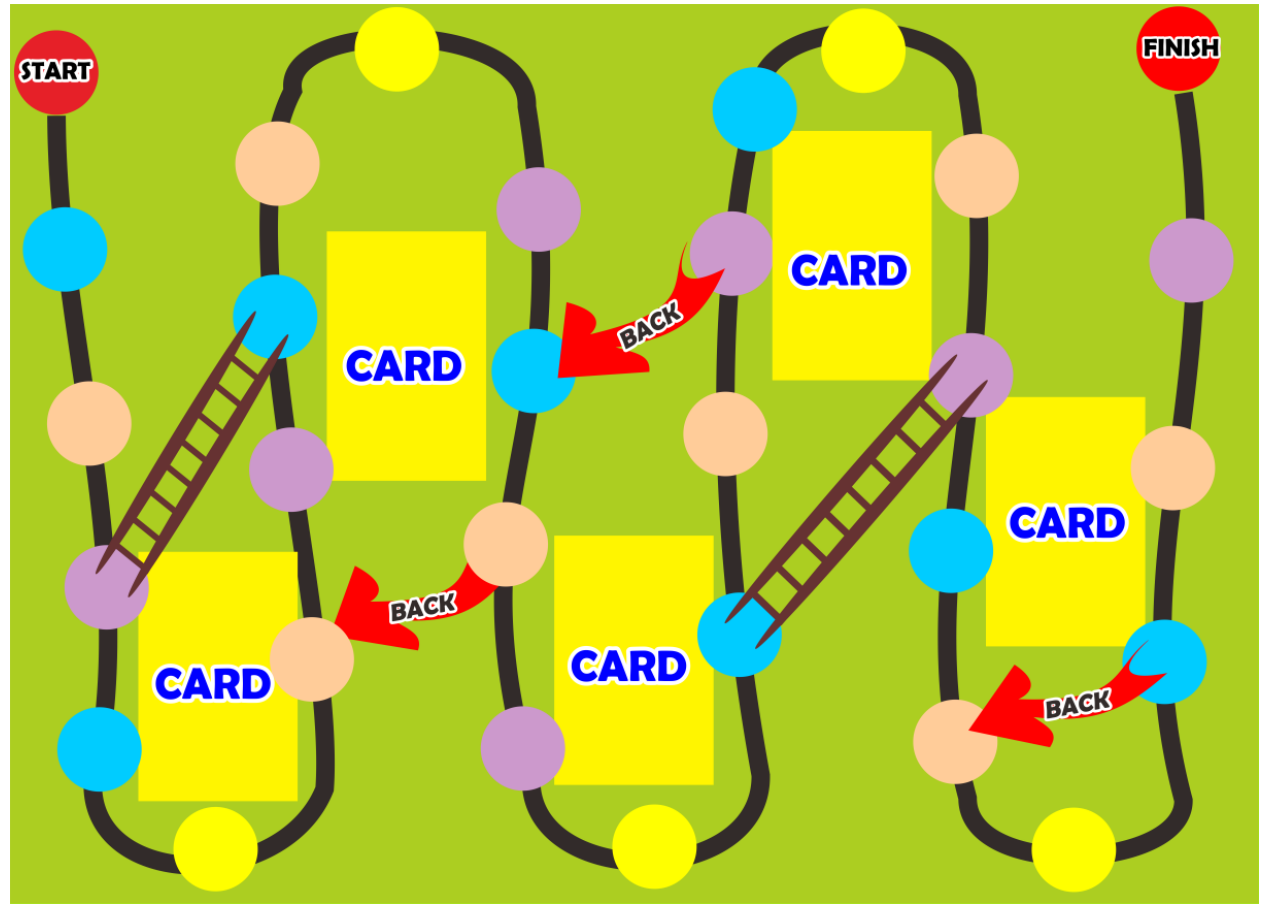

49 | IJET| Volume. 10, Issue 1. July 2021 Copyright 2021 Nur Sholikha Muntiari and Fika Megawati are licensed under Creative Commons AtrributionShareAlike 4.0 International License. 
Figure 1. Boad Game

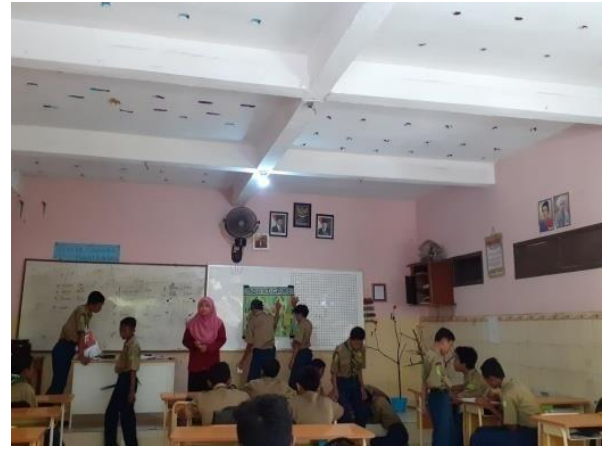

Figure 2. Doing a game

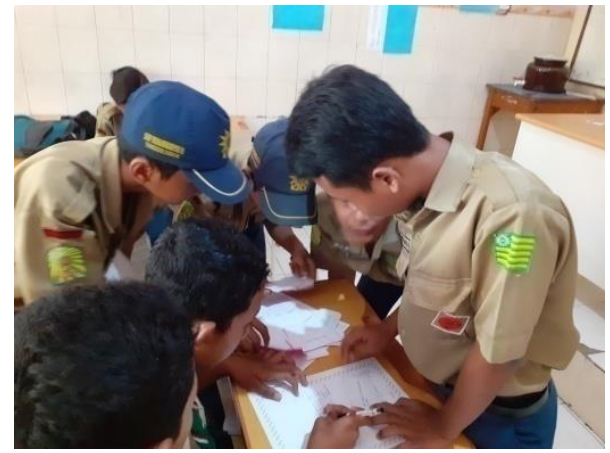

Figure. 3 Dicussion in each group

\section{FLQWGGHARTS IN USING BQARD GAME}

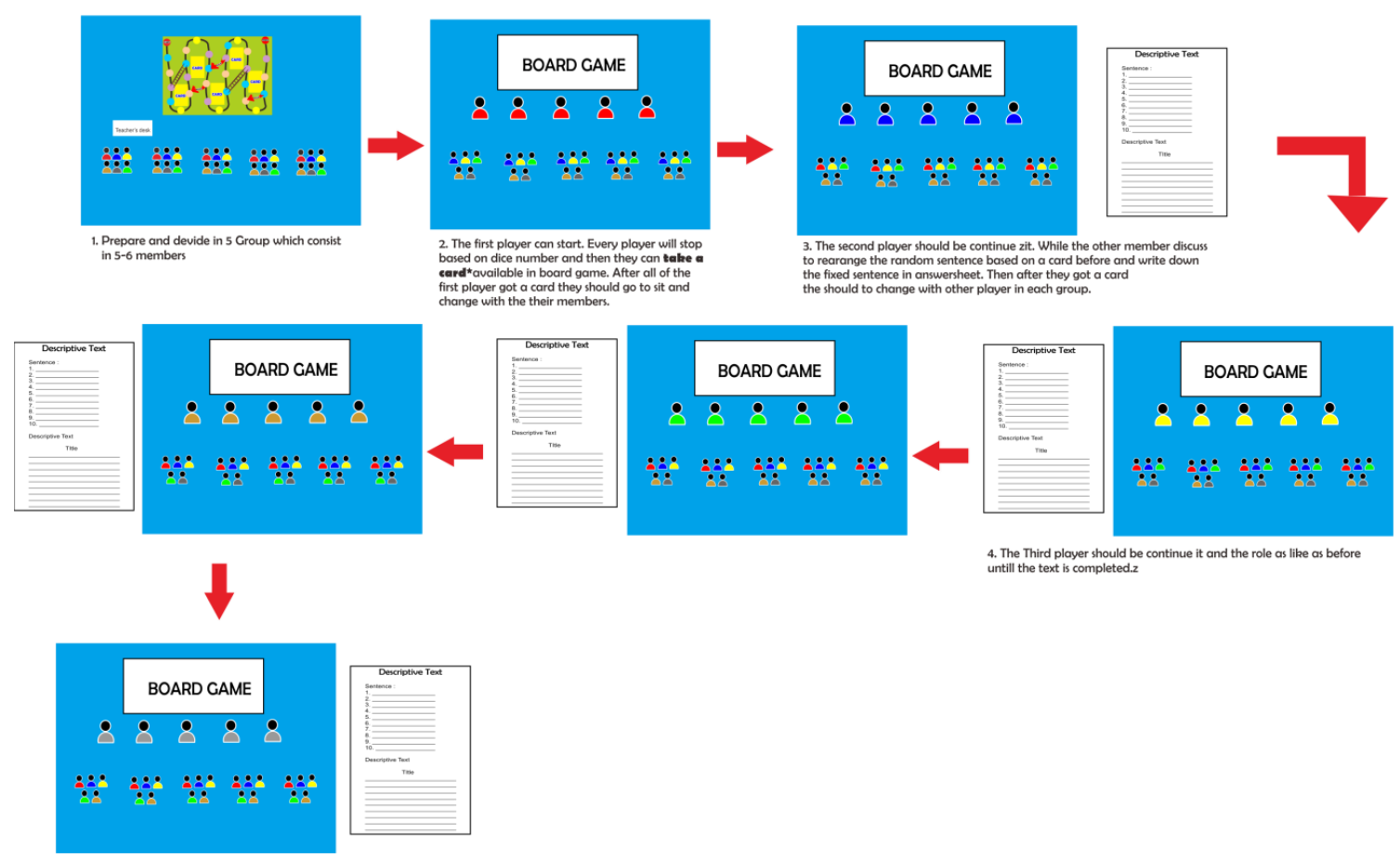

Figure 2. Flowchart in using board game

\section{RESULT AND DISCUSSION}

This study carried the data from result of pre-test and post-test from VIIB as an experimental class and control class are VIIA and VIIC. In an experimental class the students used board game as a media with TTW strategy, while in control class used conventional activities to know the results of writing students' of descriptive text. In both of them the researcher carried out in two times meeting in each class.

The first meeting in an experimental class the researcher gave a pre-test, but before it the

50 | IJET| Volume. 10, Issue 1. July 2021 Copyright 2021 Nur Sholikha Muntiari and Fika Megawati are licensed under Creative Commons AtrributionShareAlike 4.0 International License. 
researcher gave a short explanation about the general structure of descriptive text. Then, the researcher gave a treatment to explain in material about the descriptive text through TTW strategy by using board game as a media. The second meeting's activity was continuing the treatment and gave feedback to the students. The last activity in second meeting was giving posttest for measuring students' understanding about it after got a treatment. There is significant different for the pre-test and post test in both of them.

Table 1. Learning Process

\begin{tabular}{|c|c|c|}
\hline Meeting & Experimental Class & Control Class \\
\hline Meeting 1 & $\begin{array}{l}\text { - Teacher shown example of about } \\
\text { descriptive text } \\
\text { - Teacher asked the student to make a group } \\
\text { consist of 5-6 members to aplyed in TTW } \\
\text { Strategy } \\
\text { - Students discuss in their own group about } \\
\text { clue-card that they got from board game } \\
\text { before (applied in think and talk activity } \\
\text { of TTW strategy) } \\
\text { - Students rearrange the random sentence to } \\
\text { be a correct sentence } \\
\text { - The students made a short paragraph of } \\
\text { descriptive text based on previous } \\
\text { sentencesn answer sheet (applied in write } \\
\text { activity of TTW strategy) } \\
\text { - Students have collected the full } \\
\text { descriptive text in front of the class }\end{array}$ & $\begin{array}{l}\text { Teacher gave the } \\
\text { material about } \\
\text { descriptive text } \\
\text { - Students asked to } \\
\text { finished assignment } \\
\text { in LKS Bahasa } \\
\text { Inggris kelas VII in } \\
\text { group discussion }\end{array}$ \\
\hline Meeting 2 & $\begin{array}{l}\text { - Teacher has returned the full draft and } \\
\text { discuss it } \\
\text { - Teacher gave a feedback to each group }\end{array}$ & $\begin{array}{l}\text { - Teacher gave review } \\
\text { the material of } \\
\text { descriptive text for } \\
\text { the students }\end{array}$ \\
\hline
\end{tabular}

\section{a. Validation}

The some instruments have been validated in before collect the data to two validators who are an advisor and an English teacher by the researcher before.

Table 2. Validation

\begin{tabular}{|llcccc|}
\hline No & Instruments & \multicolumn{2}{c}{ Validators } & Percentages & Results \\
\cline { 3 - 4 } & & $\mathbf{1}$ & $\mathbf{2}$ & & \\
\hline 1 & Lesson plan & 76 & 60 & $85 \%$ & Very good \\
\hline 2 & $\begin{array}{l}\text { Students' } \\
\text { Worksheet }\end{array}$ & 47 & 39 & $86 \%$ & Very good \\
\hline 3 & Media & 28 & 21 & $81.6 \%$ & Very good \\
\hline
\end{tabular}

51 | IJET $\mid$ Volume. 10, Issue 1. July 2021 Copyright 2021 Nur Sholikha Muntiari and Fika Megawati are licensed under Creative Commons AtrributionShareAlike 4.0 International License. 


\section{b. Normality Test}

The aimed of this test, to calculate of comparation the scores in the sample to a normality distributed set of score with the same mean and standard deviation. The normally distributed that the data is more $\alpha=0,05$.

Table 3. The result of Normality test :

\begin{tabular}{|llcccc|}
\hline No & Instruments & \multicolumn{2}{c}{ Validators } & Percentages & Results \\
\cline { 3 - 4 } & Lesson plan & 76 & 60 & $85 \%$ & Very good \\
\hline 2 & $\begin{array}{l}\text { Students' } \\
\text { Worksheet }\end{array}$ & 47 & 39 & $86 \%$ & Very good \\
\hline 3 & Media & 28 & 21 & $81.6 \%$ & Very good \\
\hline
\end{tabular}

Based on table 3 that $\mathrm{L}_{\text {count }} \leq \mathrm{L}_{\text {tab }}$ for all of the data from pre test, and post test. It means that the data has normal distribution because $\mathrm{H}_{0}$ is accepted.

\section{c. Homogienty Test}

Homogeneity test is intended to find out whether there are different variants or not of two or more groups of data samples from populations that having same variants.

Table 4. The result of Homogeneity test:

\begin{tabular}{|c|c|c|c|c|c|}
\hline \multirow{2}{*}{$\begin{array}{c}\text { Name } \\
\text { of } \\
\text { test }\end{array}$} & \multicolumn{2}{|l|}{ Df } & \multirow{2}{*}{$\begin{array}{c}\mathbf{F} \\
\text { Counting }\end{array}$} & \multirow{2}{*}{$\begin{array}{c}\mathbf{F} \\
\text { Table }\end{array}$} & \multirow[t]{2}{*}{ Result } \\
\hline & Experimental & Control & & & \\
\hline $\begin{array}{l}\text { Pre } \\
\text { test }\end{array}$ & 15 & 31 & 0.148 & 0.447 & Homogeneity \\
\hline $\begin{array}{l}\text { Post } \\
\text { test }\end{array}$ & 15 & 31 & 2.001 & 2.003 & Homogeneity \\
\hline
\end{tabular}

In table 4 there is a significant different between $\mathrm{F}$ counting and $\mathrm{F}$ table. The data include the homogeneity test that $\mathrm{F}_{\text {counting }}<\mathrm{F}$ table. All of the data in pre test and post test it has homogeneous.

\subsection{Hypothesis Test}

a. $\mathrm{H}_{\mathrm{a}}=\mathrm{t}_{\text {count }}>\mathrm{t}_{\mathrm{tab}}$

Analysis hypothesis $=t_{\text {counting }}>t_{\text {table }}$ : there is significant difference between the students who have been though by using board game through TTW strategy and students who thought conventional teaching in writing descriptive text.

b. $\mathrm{H}_{0}=\mathrm{t}_{\text {count }}<\mathrm{t}_{\text {tab }}$

Null hypothesis $=\mathrm{t}_{\text {counting }}<\mathrm{t}_{\text {table }}$ : there is no significant difference between the students who have been though by using board game through TTW strategy and students who thought conventional teaching in writing descriptive text.

Table. 5. The result of Hypothesis test: 


\begin{tabular}{|lcclccc|}
\hline \multicolumn{1}{|c}{ Class } & Mean & $\mathbf{S}^{2}$ & $\mathbf{F}_{\text {count }}$ & $\mathbf{F}_{\text {tab }}$ & $\mathbf{T}_{\text {count }}$ & $\mathbf{T}_{\text {tab }}$ \\
\cline { 1 - 3 } Experimental & 73.81 & 61.4 & \multirow{2}{*}{1.67} & 2.00 & 5.71 & 2.31 \\
\cline { 1 - 3 } Control & 57.46 & 102,25 & & & & \\
\hline
\end{tabular}

Moreover based in table above shown that $t_{\text {count }}(5.71)>t_{\text {tab }}(2.31)$. It means that $t$ count higher than $t$ tab with $\alpha=0.05$. Then, $H_{a}$ is accepted while $H_{o}$ is rejected. So, there is an effect of students by using board game through TTW strategy in writing descriptive text.

Board game as a media that it makes has fun for the students to learning by doing based on Hornby (1990:486). In addition board game has advantages between a teacher and students based on Suryani and Rossa (2014). The teacher can increase in creativity design for board game that suitable and related for the topic. It made the students enjoyable and comfortable also has motivated in learning process activity. Absolutely, they will be more active in classroom during the learning process.

In addition, according to Megawati (2020) that some students in junior high school were bored that during learning English just asked read a book and did practice with plenty number of questions. It was boring situation for the beginner level in learning English process. Thus, the communicative way is a one of strategy to make the learning process more interactive and friendly. TTW strategy is one of strategy have been design to give a power in students' confidence (Ansori and Wiyaka, 2013).

In TTW strategy the students did think-talk-write in each member of group. Based on Sari (2018) that the participants are students of senior high school in tenth grade. Additionally, according to Sa'diyah, etc (2019) that TTW strategy is the basic to build of the think, talk and write the students. They start from think activity (dialog with the other students) after that they have to speak up and share about the topic. The last activity from TTW strategy is write, they have to write down the result of discussion or dialog with their friends on available answer.

The other words, using board game through TTW strategy in writing descriptive text has positive effect from the students, especially in seventh grade in one of junor high school. It made the learning process writing in classroom more interactive because the students can share their opinion or comments from the other friend in each group. It supported with using board game as a media made the students did not bored situation because they can learn by doing.

\section{CONCLUSION}

Board game is a media which has combination between rules of play snake and ladder's game and monopoly. It used a dice number to apply it and put an icon to give identity in each group. While, Think-Talk-Write (TTW) is a strategy in which have 5-6 members of group. The students make a group which in one group involving student to think and discuss by themselves after read of the clue card which gotten in before based on using board game as a media.

In addition, talk and share their ideas with their friends before they write it. This strategy, the students build a good communication in each group to achieve the goals. In addition, board game as a media gives motivation and spirit for students to succeed together. Based this research, the researcher conclude that using board game through TTW strategy gives positive effect for writing skill in descriptive text on seventh grade students in junior high school.

53 | IJET| Volume. 10, Issue 1. July 2021

Copyright 2021 Nur Sholikha Muntiari and Fika Megawati are licensed under Creative Commons AtrributionShareAlike 4.0 International License. 
The researcher will thank to the subjects of this research. The researcher also submits appreciation to the anonymous reviewers for the positive comments on this post.

\section{REFERENCE}

Arif, M. (2018). The Use of Snake and Ladder Game and Cooperative Learning to Improve Students'Speaking Skill. IAIN Salatiga.

Brown, H. D. (2007). Principles of Language Learning and Teaching. Longman.

Huinker, D., L. C. (1996). Talk Your Way Into Writing (P. C. E. and M. J. Kenny (ed.); Year Book). NCTM.

Nurfaujiyah, S., \& Riandi. (2013). The Influence of Think, Talk, and Write (TTW) Strategy towards Students' Descriptive Writing Mastery.

Paris, T. N. ., \& Yussof, R. . (2013). Use of Time 'Trap Board Game' to Teach Grammar. In Asia pasific International Conference on Evironment-Behaviour Studies.

Putri, \& Sukirlan. (2017). The Implementation of Board Game in Improving Students' Speaking Skill.

Ramadani, V., \& Saun, S. (2013). Helping Junior High School Students in Writing Descriptive Text through Draw-Label-Caption Strategy. Universitas Negeri Padang.

Setyadi, D., \& Qohar, A. (2017). Pengembangan Media Pembelajaran Matematika Berbasis Web Pada Materi Arisan dan Deret. Universitas Negeri Surabaya.

Suminar, P. R., \& Putri, G. (2015). The Effectiveness of TTW (Think-Talk-Write) Strategy in Teaching Writing Descriptive Text. University of swadaya Gunung Jati.

54 | IJET| Volume. 10, Issue 1. July 2021

Copyright 2021 Nur Sholikha Muntiari and Fika Megawati are licensed under Creative Commons AtrributionShareAlike 4.0 International License. 